\title{
The RNA Society: after 20 years clearly a big success
}

\author{
JOHN ABELSON \\ Department of Biochemistry and Biophysics, University of California - San Francisco, San Francisco, California 94143-2200, USA
}

This 20th anniversary of the RNA journal is a time to look back on what we have accomplished and perhaps more important to decide what is important for the future.

I won't reiterate Olke Uhlenbeck's “Imperfect Account of the Founding of the RNA Society." You can find that account on our website. I am glad Olke wrote it down when he did because you wouldn't want the aging founders to write it now. But I do remember quite well the elements I thought we needed.

1. I thought it important that we have a society journal and that the journal should be rigorous in its review of the science but should not be a magazine. We even knew then that the criteria for a Science, Nature or Cell paper were not solely that the science be rigorous but that the material be "trendy." Of course that is much worse now than it was then (or maybe we are no longer trendy). Serious peer reviewed publication of scientific results is important for getting a job, for academic advancement and for grant renewals. It is clear that we have accomplished what we set out to do in this regard.

2. I thought that we should own the journal. The model for this is the JBC owned by ASBMB and the Protein Journal owned by the Protein Society. When the society owns the journal it can determine the policies of the journal and can maintain those policies. This would not necessarily be true if the journal is owned by a large publishing house. Furthermore I was aware that the ASBMB is wealthy because of its ownership of the JBC.

3. We had been having various RNA processing meetings, first at Brookhaven and then for a number of years at Cold Spring Harbor. We wanted to formalize the nature and organization of an annual meeting. Our meetings have been a huge success because from the first the policy was that short talks be given by students (perhaps the early phage meetings were a model for this). But even more important, and this was never a written policy, was that the PIs be there and that they attend the talks. When a student gives a talk and he or she knows that the likes of Joan Steitz, Tom Cech, and Olke Uhlenbeck are sitting in the front row the talk takes on much more significance. All of the labs in this field work very hard with their students in preparing these talks and the sense of accomplishment in pulling it off is a priceless reward for the effort.

For the future, I think we face a different and more difficult set of problems. We all know that the path the scientists of my era followed: Write a good thesis, do a good postdoc and get an academic job is much more difficult now. It is clear that our students understand this. I will not suggest solutions for this problem here but I have faith that our former students, now the leaders of the society, will take them on.
Corresponding author: johnabelson@gmail.com

Article and publication date are at http://www.rnajournal.org/cgi/doi/ 10.1261/rna.049767.115. Freely available online through the RNA Open Access option.
(C) 2015 Abelson This article, published in RNA, is available under a Creative Commons License (Attribution-NonCommercial 4.0 International), as described at http://creativecommons.org/licenses/by-nc/4.0/. 

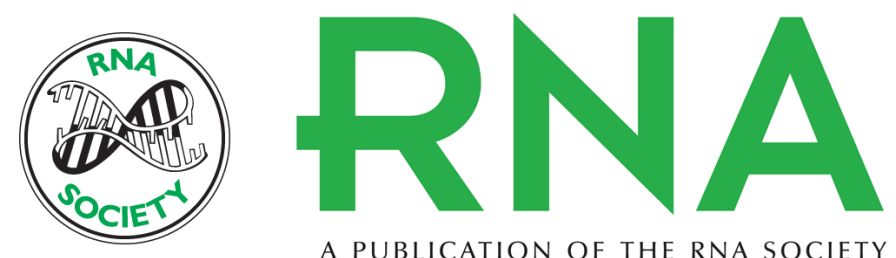

A PUBLICATION OF THE RNA SOCIETY

\section{The RNA Society: after 20 years clearly a big success}

John Abelson

RNA 2015 21: 480

Open Access Freely available online through the RNA Open Access option.

Creative This article, published in $R N A$, is available under a Creative Commons License

Commons (Attribution-NonCommercial 4.0 International), as described at

License http://creativecommons.org/licenses/by-nc/4.0/.

Email Alerting Receive free email alerts when new articles cite this article - sign up in the box at the Service top right corner of the article or click here.

To subscribe to $R N A$ go to:

http://rnajournal.cshlp.org/subscriptions

(C) 2015 Abelson; Published by Cold Spring Harbor Laboratory Press for the RNA Society 